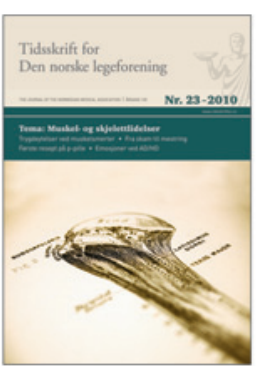

\section{Klinisk kommunikasjon - livslang læring}

I Tidsskriftet nr. 23/2010 har Hege Gjessing interessante refleksjoner omkring legers kommunikasjon med sine pasienter (1). Vi som har ansvaret for denne delen av undervisningen ved Avdeling for atferdsfag, Det medisinske fakultet, Universitetet i Oslo, deler hennes synspunkter på kommunikasjonens avgjørende rolle både for optimal informasjonsinnhenting og for oppbygging av en trygg relasjon mellom pasient og lege. Vi er også enige i at kommunikasjon, som del av de generelle kliniske ferdigheter, bør ivaretas i utdanning og etterutdanning. Gjessing påpeker at kunnskaper om kommunikasjon svært ofte avlæres når leger fanges av travle arbeidsdager. Heldigvis er ikke dette bildet ensidig dystert.

I EKKO-prosjektet (Evaluering av Klinisk KOmmunikasjon i medisinstudiet) ble et utvalg studenter fra alle landets medisinske fakulteter (omtrent en tredel av avgangskullene våren 2004) vurdert bl.a. på kliniske kommunikasjonsferdigheter et par måneder før embetseksamen. Mange av de samme ble igjen vurdert ved avslutningen av turnustjenesten (våren 2006). Vurderingen ble foretatt ved skåring av videoopptak av en konsultasjon som studentene (senere som turnusleger) gjennomførte med en simulert pasient (skuespiller) $(2-8)$.
Resultatene viste at det skjedde en signifikant forbedring av de kliniske kommunikasjonsferdighetene i dette utvalget gjennom turnusperioden, i størst grad for kvinnelige deltakere. Imidlertid viste studien at en god del ikke hadde nådd et tilfredsstillende ferdighetsnivå, verken ved studieslutt eller ved turnusslutt. Derfor er vektlegging av fortsatt læring av kliniske kommunikasjonsferdigheter, også etter studiets slutt, av stor betydning.

\section{Tore Gude}

tore.gude@medisin.uio.no

Tore Gude (f. 1940) er professor emeritus ved Avdeling for medisinsk atferdsvitenskap, Institutt for medisinske basalfag, Universitetet i Oslo.

Oppgitte interessekonflikter: Forfatteren er lærer i klinisk kommunikasjon.

\section{Litteratur}

1. Gjessing H. Kommunikasjon må trenes. Tidsskr Nor Legeforen 2011; 131: 2387

2. Gude T, Vaglum P. Anvik T et al. Do physicians improve their communication skills between finishing medical school and completing internship? A nationwide prospective observational cohort study. Patient Educ Couns 2009; 76: 207-12.

3. Anvik T, Gude T, Grimstad H et al. Assessing medical students' attitudes towards learning communication skills - which components of attitudes do we measure? BMC Med Educ 2007; 7: 4

4. Anvik T, Grimstad H, Baerheim A et al. Medical students' cognitive and affective attitudes towards learning and using communication skills - a nationwide cross-sectional study. Med Teach 2008; 30: 272-9.

5. Baerheim A, Hjortdahl P, Anvik T et al. Curriculum factors influencing knowledge of communication skills among medical students. BMC Med Educ 2007; 7: 35.

6. Gude T, Baerheim A, Holen A et al. Comparing self-reported communication skills of medical students in traditional and integrated curricula: a nationwide study. Patient Educ Couns 2005; 58 : 271-8.
7. Gude T, Hjortdahl P, Anvik T et al. Does change from a traditional to a new medical curriculum reduce negative attitudes among students? A quasi-experimental study. Med Teach 2005; 27 . 737-9.

8. Gude T, Vaglum P, Baerheim A et al. Observed communication skills: how do they relate to the consultation content? A nationwide, observational study of medical students seeing a standardized patient for the first time in a general practice setting. BMC Med Educ 2007; 7: 43

\section{RETTELSER}

Levealder og dødsårsaker hos menn undersøkt ved helsekontroll i 1964

Tor Bjerkedal, Petter Kristensen, Randi Selmer

Tidsskr Nor Legeforen 2012; 132: $30-5$

På side 32 i tabell 3 linje 37 skal det stå: Kroppsmasseindeks (BMI) $\left(\mathrm{kg} / \mathrm{m}^{2}\right)$.

Tilsvarende skal det på side 33 i tredje linje i teksten til figur 2 stå: ... fedme: $\mathrm{BMI} \geq 30 \mathrm{~kg} / \mathrm{m}^{2}$ versus $18,5-24,99 \mathrm{~kg} / \mathrm{m}^{2} \ldots$

Vi beklager feilen. Den er rettet i nettutgaven.

\section{Hvor lenge varer et svangerskap?}

Torvid Kiserud

Tidsskr Nor Legeforen 2012; 132: 8-9

I lederen på s. 8 i Tidsskriftet nr. 1/2012 skal illustrasjonsteksten være:

Variasjon i svangerskapslengde i 309749 enkeltsvangerskap etter sikker siste menstruasjon (rød kurve) og spontan fødselsstar i 1999-2010 (median lengde 283 dager). Gul kurve viser fordelingen for de samme svangerskapene, men basert på ultralyddatering (median estimert svangerskapslengde 281 dager). Data fra Medisinsk fødselsregister Vi beklager feilen. Den er rettet i nettutgaven. 